See discussions, stats, and author profiles for this publication at: https://www.researchgate.net/publication/328366894

\title{
Consumers' behaviour in fast-food restaurants: a food value perspective from Spain
}

Article in British Food Journal · October 2018

DOI: 10.1108/BFJ-01-2018-0059

CITATIONS

4 authors, including:

Alicia Izquierdo Yusta

Universidad de Burgos

54 PUBLICATIONS 350 CITATIONS

SEE PROFILE

0

María Pilar Martinez-Ruiz

University of Castilla-La Mancha

123 PUBLICATIONS 763 CITATIONS

SEE PROFILE

Some of the authors of this publication are also working on these related projects:

Cyborg Ethics View project

From marketing 3.0 to marketing 4.0. Attachment, brand love and engagement View project
Jorge Pelegrín Borondo

Universidad de La Rioja (Spain)

33 PUBLICATIONS 69 CITATIONS

SEE PROFILE 


\section{e emeraldinsight}

\section{British Food Journal}

Consumers' behaviour in fast-food restaurants: a food value perspective from

Spain

Alicia Izquierdo-Yusta, Carmen M. Gómez-Cantó, Jorge Pelegrin-Borondo, María Pilar Martínez-Ruiz,

\section{Article information:}

To cite this document:

Alicia Izquierdo-Yusta, Carmen M. Gómez-Cantó, Jorge Pelegrin-Borondo, María Pilar Martínez-Ruiz, (2018) "Consumers' behaviour in fast-food restaurants: a food value perspective from Spain", British

Food Journal, https://doi.org/10.1108/BFJ-01-2018-0059

Permanent link to this document:

https://doi.org/10.1108/BFJ-01-2018-0059

Downloaded on: 18 October 2018, At: 02:19 (PT)

References: this document contains references to 66 other documents.

To copy this document: permissions@emeraldinsight.com

Access to this document was granted through an Emerald subscription provided by emeraldsrm: 409342 []

\section{For Authors}

If you would like to write for this, or any other Emerald publication, then please use our Emerald for Authors service information about how to choose which publication to write for and submission guidelines are available for all. Please visit www. emeraldinsight.com/ authors for more information.

\section{About Emerald www.emeraldinsight.com}

Emerald is a global publisher linking research and practice to the benefit of society. The company manages a portfolio of more than 290 journals and over 2,350 books and book series volumes, as well as providing an extensive range of online products and additional customer resources and services.

Emerald is both COUNTER 4 and TRANSFER compliant. The organization is a partner of the Committee on Publication Ethics (COPE) and also works with Portico and the LOCKSS initiative for digital archive preservation.

*Related content and download information correct at time of download. 


\title{
Consumers' behaviour in fast-food restaurants: a food value perspective from Spain
}

Consumers' behaviour in fast-food restaurants

\author{
Alicia Izquierdo-Yusta \\ University of Burgos, Burgos, Spain \\ Carmen M. Gómez-Cantó \\ Facultad de Ciencias Economicas y Empresariales, \\ Universidad de Castilla-La Mancha, Ciudad Real, Spain \\ Jorge Pelegrin-Borondo \\ Universidad de la Rioja, La Rioja, Spain, and \\ María Pilar Martínez-Ruiz \\ University of Castilla-La Mancha, Albacete, Spain
}

Received 6 February 2018

Revised 21 June 2018

Accepted 21 June 2018

\begin{abstract}
Purpose - The purpose of this paper is to understand consumers' behaviour in fast-food restaurants in Spain. To this end, the authors conducted a survey that combined a classification of food values, as proposed in the relevant literature, with a related model that links personal values to behaviour.

Design/methodology/approach - A sample of 400 consumers was gathered from two different, leading fast-food chains operating in Spain. With these data, respondents were grouped through hierarchical cluster analysis and $K$-measures, and in accordance with Lusk and Briggeman's (2009) food values and the food-related lifestyle model. The authors validated these clusters by means of ANOVA and discriminant analysis, which led to useful observations about inter-group differences in consumers' habits, as well as their satisfaction, trust and loyalty.

Findings - The results indicate that consumers can be clustered into three groups based their food values assessments: the "mainly utilitarian" group, the "mainly hedonic" group and the "ethical values" group. These groups not only demonstrate diverse habits, but also differ on key variables such as satisfaction, trust and loyalty.

Practical implications - The authors offer several managerial recommendations for designing and developing segmentation strategies in the fast-food industry. Any such strategies should acknowledge that all consumer groups appear to value restaurants' efforts to provide them with both hedonic and utilitarian benefits, although the extent varies across groups.

Originality/value - Among the relevant literature, this research is the only one that examines the existence of distinct consumer groups based on their food values assessments. In addition, this paper analyses inter-group differences in terms of both diverse consumptions habits (frequency of visits, expenditure, etc.) and key marketing variables (satisfaction, trust and loyalty).
\end{abstract}

Keywords Values, Loyalty, Trust, Satisfaction, Cluster, Consumer habits

Paper type Research paper

\section{Introduction}

Over the last few decades, the process of globalisation has led to important cultural and sociological changes that have seeped into consumers' habits and culinary preferences. For instance, today's consumers exhibit a heightened sensitivity about the food they eat, and their anxieties are wide-ranging: from the dangers of food poisoning, to the broad health impact of food (e.g. chemical additives, high fat content and the related chronic diseases), to the environmental and regulatory issues surrounding food production (Worsley and Lea, 2008). These concerns have arisen in tandem with many consumers spending less time buying and cooking their own meals (Ayechu and Durá, 2010).

In light of these developments, the restaurant industry operators are challenged to design and develop strategies tailored to specific market segments. However, the restaurant

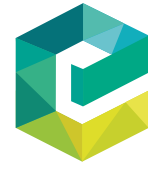

British Food Journa (C) Emerald Publishing Limited 0007-070X 
sector is already highly atomised: on the supply side, for instance, companies cater to very specific consumer segments (vegetarian, organic, etc.) or adapt their offer to segments with specific needs (e.g. gluten intolerance). This trend has similarly compelled producers and manufacturers to offer segment-specific products in order to better meet consumers' needs. Hence, restaurants need more refined strategies in order to differentiate themselves from their competitors and gain thorough knowledge of their customers (e.g. Kivela, 1997; Koo et al., 1999).

This need is especially pronounced among fast-food restaurants, which are an increasingly important sector of the industry. As one of the most iconic forms of globalisation, fast-food restaurants have spread rapidly to major cities all over the world in response to the changing habits of urban consumers (Schroeder and McEachern, 2005; Tong and Wong, 2016; Xu, 2014). Such restaurants draw consumers for several reasons: convenience and/or time savings (Clemente-Ricolfe and Gómez-Layana, 2006); the pleasure of enjoying this type of family meal (Darian and Cohen, 1995); the positive image that they project when marketed as establishments of youthful and modern food (Fàbrega, 2004); their low price, wide schedules and service speed, or even food offerings that are healthier and more respectful towards the environment (Libremercado, 2016).

Operators can use several variables to design and develop such segmentation strategies. The common tradition has been to use socioeconomic and demographic variables such as gender, age, standard of living and education. However, there has been recent interest in new features stemming from consumers' values. Within this latter research stream, it is worth highlighting the food values scale proposed by Lusk and Briggeman (2009), who classified food values based on a review of the literature on food preferences and human values. Also worth noting is the food-related lifestyle (FRL) model proposed by Grunert et al. (1993), which tries to explain consumers' behaviour towards their food choices in terms of their individual FRLs. The FRL model effectively proposes a relationship between the product and value attainment (although such a relationship can be more or less indirect).

There are at least three strategic reasons for fast-food operators to consider this research stream: the need to identify how the health issues surrounding fast food (such as the observed relationship between its consumption and weight gain and/or obesity; Currie et al., 2010) might affect consumers' perception of the firm's image; the growing need to establish long-term relationships with customers, which requires a detailed analysis of their behaviours; and the intensive competitive environment of the fast-food industry and the subsequent need for long-term survival strategies (Law et al., 2004; Momtaz et al., 2013).

Given the above, the present study seeks a better comprehension of the behaviours of fast-food consumers in Spain - specifically, how to achieve and/or bolster their satisfaction with, trust in and loyalty towards this type of store. This research hopes to provide managers with a greater understanding of different consumer segments and their respective food values - and further, how these values relate to satisfaction, trust and loyalty. With this intention in mind, we adopted Lusk and Briggeman's (2009) food values classification, which reflects many of the previously mentioned tendencies and is consistent with the precepts of the FRL model, to classify fast-food consumers into different clusters. This will enable us to investigate significant differences in those clusters' habits and non-financial metrics (satisfaction, trust and loyalty). Based on the results, we will propose a series of recommendations for the managers of fast-food restaurants.

\section{Literature review}

\subsection{The relevance of values}

As previously pointed out, the past few decades have seen several shifts in how people purchase and consume food. In order to sustain a competitive advantage, fast-food business managers need to understand the aspects that guide consumer preferences and then 
incorporate those aspects in their marketing strategies (Abdullah et al., 2011). It is in this vein that the work of Lusk and Briggeman (2009) becomes especially useful. Their paper developed a classification of food values, reflecting a set of beliefs regarding the relative importance of the meta-attributes, consequences and desired end-states associated with purchasing and consuming food. Having built the values upon a deep literature review on food preferences and human values, the authors created a system that recognises consumers as complex and multi-dimensional (Martínez-Ruiz and Gómez-Cantó, 2016). Indeed, these values encompass most of the previously highlighted aspects, such as the growing concern for nutrition (nutrition and safety values), the natural environment (environmental impact value), social justice (fairness, origin, tradition and naturalness values) and whose consumption evokes feelings and provides experiences (appearance, taste and convenience values). By considering these values, fast-food restaurants may be able to develop better segmentation strategies.

In the food research domain, it is common to see values linked to consumers' lifestyles. One of the commonly used models in this field is Grunert's (1993) FRL model, which relates to the systems of cognitive categories, scripts and their associations, which relate a set of food products to a set of values (Grunert et al., 1993). The system of cognitive structures that the FRL contains is assumed to include different kinds of cognitive schemas related to food, purchase motives and food quality aspects, as well as broad cognitive scripts related with cooking methods, ways of shopping and consumptions situations (Grunert et al., 1993).

The FRL and food values scale overlap in a few ways. For one, the model proposes a relationship between the food product and value attainment (although this relationship could be indirect depending on the product, the usage situation and the way that food products are transformed into meals) (Steenkamp and Van Trijp, 1990). This relationship reflects consumers' freedom in how they try to use food products to attain values and difficulties that the consumer chooses food products directed by expected value attainment. Second, the desired higher-order product attributes that underpin the FRL model refers to attributes that may apply to food products in general, such as natural, nutritious, convenient, etc. These latter attributes are considered by the values proposed by Lusk and Briggeman (2009).

\subsection{The customer-business relationship}

Businesses exist and compete to create satisfied customers (Anderson and Fornell, 2000). Investors are attracted to companies that excel at satisfying their customers, as those firms recognise that the amount of goods or services they produce matters less than convincing customers to return. In the restaurant industry, providing a variety of fresh, healthy food remains an important criterion for satisfying customers (Qin et al., 2010), but companies must also offer dining experiences that combine tangible and intangible elements in order to meet or exceed customers' expectations (Tarn, 1999).

In the past, when fast-food companies were more novel, they could satisfy customers simply through tangible offerings (i.e. the food itself). However, people have become more gastronomically sophisticated, and consequently, they have become more demanding about their dining expectations. For example, newer generations are shifting away from the traditional towards the new, the innovative and the exciting - all of which are intangible qualities. While many traditionalists might believe that innovation can only be achieved through tangible elements, such as the introduction of a new food item, intangible aspects have the power to evoke deep, long-lasting emotions and memories (Zopiatis and Pribic, 2007).

This trend towards the novel and intangible is largely driven by younger consumers, perhaps indicating the importance they attribute to hedonic (i.e. subjective and individualistic) consumption. Hedonic consumption provides these consumers with joy
Consumers'

behaviour in fast-food restaurants 
and pleasure (Irani and Heidorzaden, 2011) through the multisensorial, fantasy and emotional aspects derived from their experience with the product (Hirschman and Holbrook, 1982). In the context of fast-food restaurants, such hedonic benefits might be derived from the food's good taste, among other features (Maehle et al., 2015). The flip side of hedonic consumption is utilitarian consumption, which is more "rational" and focussed towards an objective (Arnold and Reynolds, 2003). This implies that consumers acquire products in an efficient way and for a functional purpose (Hirschman and Holbrook, 1982; Strahilevitz and Myers, 1998). In the fast-food context, utilitarian benefits might take the form of low prices, for example (Maehle et al., 2015).

In practice, though, the majority of products seek to provide a combination of hedonic and utilitarian benefits, albeit with different degrees of emphasis. However, consumers frequently consider the majority of products as exclusively hedonic or utilitarian (Batra and Ahtola, 1990; Fuljahn and Moosmayer, 2011). For this reason, Ryu et al. (2010) divided fastfood customers based on whether they professed a hedonic or utilitarian motivation for patronising such restaurants. This research found that both hedonic and utilitarian values significantly influenced customer satisfaction and behavioural intentions, and that customer satisfaction played a significant role in changing behavioural intentions.

Based on the above, restaurateurs should seek to improve customers' perceptions of both hedonic and utilitarian values to ensure satisfaction and encourage positive behaviours and emotions, such as returning to the restaurant or talking positively about their dining experience. Thus, managing customer satisfaction levels is a critical strategy for fast-food restaurants to retain current customers and attract new business via word-of-mouth (Qin and Prybutok, 2008).

In order to enact this strategy, companies need to build trust built with consumers, which is required for positive outcomes such as customer loyalty, retention, purchase intention, willingness to act and overall market performance (Erdem and Swait, 2004).

However, most of the extensive research on brand trust has focussed more on the results of trust (e.g. loyalty and repeat business) than its predictors. For instance, Jacoby and Chesnut (1978) found that loyalty is a behavioural result of consumers' preferences for one brand over a selection of similar brands over a given period of time, which influences the evaluative process involved in decision-making. As a result, they suggested analysing loyalty from a twofold perspective: behavioural and attitudinal. Earlier studies often pursued the former approach: Dick and Basu (1994), for example, defined loyalty as the relationship between the "relative attitude" towards an entity (brand/store/vendor) and "patronage behaviour". However, more recent studies have adopted an attitudinal approach (De Ruyter et al., 1998) in order to provide a fuller picture.

Still, there is a largely answered question about what builds trust in consumers. With a focus on the service sector, Parasuraman et al. (1985) suggested that trust arises for clients when they feel secure with how they are treated and trust that any information they might provide will be kept confidential. Several authors have since translated this issue of perceived service quality to the fast-food industry, finding that factors such as food taste, establishment cleanliness, service speed and staff friendliness impact customer satisfaction and loyalty (Qin and Prybutok, 2009a, b; Qin et al., 2010). Price and nutritional value are gaining increasing importance, though (Kara et al., 1995), as are convenient operating hours. With regard to food products, trust is closely linked to other basic marketing concepts such as safety, nutrition and health. Trust is also a potentially important factor in consumers' purchasing behaviour towards food products (Bredahl, 2001). Consumers sometimes lose their trust in the food production chain and fear that their health could be seriously compromised (cf. Worsley and Lea, 2008), and then it might become necessary to restore said trust. Such considerations are crucial for companies trying to gain customer loyalty and expand their persistent customer base. 
In any case, it is clear that consumer trust, loyalty and satisfaction are interconnected constructs. For instance, several studies have determined that high customer satisfaction and service quality result in higher customer loyalty and a willingness to recommend a firm to another person (Bolton and Drew, 1991; Boulding et al., 1993; Rust and Oliver, 1994). Likewise, Anderson and Sullivan (1993) found that a high level of customer satisfaction decreases the perceived benefits of switching service providers, which, in turn, increases customers' repurchasing intentions and loyalty. By defining loyalty in terms of purchase frequency and amount spent per order or visit, Kendrick (1998) effectively implied that customers must be satisfied in order to become loyal to and profitable for a company. Bowen and Chen (2001) corroborated this argument in their study on the relationship between customer loyalty and customer satisfaction, finding a positive correlation between loyal customers and profitability. Similarly, Kumar and Shah (2004) noted that customer loyalty is an important part of developing relationships that increase business and promote retention.

Relatedly, many researchers have provided empirical evidence for a positive relationship between customer satisfaction and behavioural intentions such as returning to an establishment or recommending it to friends - all of which have obvious implications for profitability (Ryu et al., 2010). Moreover, high levels of satisfaction have the collateral effect of reducing the amount of money that needs to be invested in attracting new customers, as loyal customers effectively fill that role for free (Lovelock and Wright, 2002).

\section{Methodology}

\subsection{Data collection}

In order to collect the data, we developed a structured questionnaire that intended to gather all the necessary information for the research. In order to keep the sampling error below 5 per cent, we conducted 400 personal surveys at the exit of different McDonald's and Telepizza establishments located in the city of Burgos (Spain) in 2013. We selected these fast-food chains because McDonald's is the leading fast-food chain in Spain, and Telepizza is one of the Spanish-originating brands that has achieved a consolidated image and global coverage. We chose the city of Burgos because its population size is fairly representative of most Spanish cities (Caixabank Research, 2014). The restaurants were visited at different times of day and over the course of several months so as to ensure that the data would not be seasonal. The survey was voluntary and completely anonymous, and consumers did not receive any kind of incentive (Table I).

\subsection{Empirical research}

Most marketers understand that mass marketing is an ineffective approach to meeting diverse customer needs. Grouping customers with similar requirements and buying behaviour into segments is one way to address this diversity. In doing so, marketing managers are likely to reach their target market(s) far more effectively and efficiently, and thereby better satisfy their customers' needs.

Universe

Sample unit

Data collection method

Sample error

Level of trust

Sample procedure

Number of surveys
Consumers of fast-food restaurants over the age of 18 (September-October 2013)

Consumer of fast-food restaurants over the age of 18 (September-October 2013)

Personal questionnaire

$\pm 4.92 \%$

$95 \% ; Z=2 ; P=Q=0.50$

Probabilistic method

400 valid surveys
Consumers'

behaviour in fast-food restaurants 
We utilised a sequential process to meet the objectives of determining, analysing and characterising consumer groupings at fast-food restaurants. First, we built upon the food values identified by Lusk and Briggeman (2009) to form user groups through hierarchical cluster analysis and $K$-measures. In a second phase, we validated these clusters by means of ANOVA and discriminant analysis. In a third and final phase, we performed parametric and non-parametric tests to uncover the existence of inter-group differences in terms of satisfaction, trust, loyalty and consumer habits.

\subsection{Results and discussion}

In the hierarchical cluster analysis, we used squared Euclidean distance as the measure of proximity and the Ward method as the classification algorithm. This produced a dendrogram that allowed us to determine the number of clusters and the centroids, which was necessary to apply the $K$-means method. We obtained a total of three clusters, which were validated by both ANOVA and discriminant analysis. The ANOVA results reflect the existence of inequality of means between the groups (see Table II).

The following paragraphs offer a brief description of the groups. The clusters were formed by taking the average values of the variables, which are shown in Table II:

- Group 1. Mainly utilitarian: people in this group place importance on the price paid for food. They also attach considerable value to appearance and taste. They gave the remaining values lower scores than the other respondents. A total of 34.5 per cent of the sample belonged to this group. Although these consumers emphasise values related to both utilitarian and hedonic benefits, we coded this group as "mainly utilitarian" due to the high relevance they assigned to price.

- Group 2. Mainly hedonic: accounting for 24 per cent of the sample, this group comprises those consumers who value all aspects highly except for price. Like Group 1, these consumers place a high emphasis on values related to both utilitarian and hedonic benefits, but we coded this group as mainly hedonic due to the high importance placed on appearance, taste (especially with respect to Group 3) and convenience (especially with respect to Group 1).

- Group 3. Ethical values: The people in this group were the least concerned about the price, taste and appearance, and instead identified with a range of values related to health, the environment and social responsibility (for simplicity's sake, we will jointly refer to them as "values"). They also emphasised aspects such as naturalness,

Table II.

Mean values of the variables between groups and the ANOVA

\begin{tabular}{|c|c|c|c|c|}
\hline & $\begin{array}{l}\text { Group 1: Mainly } \\
\text { utilitarian }\end{array}$ & $\begin{array}{l}\text { Group 2: Mainly } \\
\text { hedonic }\end{array}$ & $\begin{array}{l}\text { Group 3: Ethical } \\
\text { values }\end{array}$ & ANOVA \\
\hline Appearance & 3.94 & 4.33 & 3.30 & $39.75^{*}$ \\
\hline Taste & 4.37 & 4.60 & 3.59 & $56.74 *$ \\
\hline Price & 3.99 & 3.75 & 3.14 & $24.96^{*}$ \\
\hline Naturalness & 2.04 & 3.95 & 2.61 & $121.74 *$ \\
\hline Convenience & 2.17 & 4.11 & 3.17 & $101.92 *$ \\
\hline Nutrition & 1.87 & 3.75 & 3.20 & $102.22^{*}$ \\
\hline Origin & 2.00 & 3.68 & 2.51 & $74.13^{*}$ \\
\hline Tradition & 1.85 & 3.94 & 3.39 & $139.84^{*}$ \\
\hline Environmental impact & 2.75 & 4.15 & 3.38 & $40.64 *$ \\
\hline Safety & 2.28 & 3.97 & 3.04 & $68.32^{*}$ \\
\hline Fairness & 1.91 & 4.08 & 2.71 & $73.48^{*}$ \\
\hline \multicolumn{5}{|c|}{ Note: *Level of significance $<0.001$} \\
\hline
\end{tabular}


nutrition, origin, tradition, environmental impact, safety and fairness. This group accounted for the largest share of users (41.5 per cent).

The multiple discriminant analysis revealed the existence of differences in means between the groups (i.e. the equality of means). In addition, low Wilks' $\lambda$ values were observed. The $\chi^{2}$ associated with the Wilks' $\lambda$ means that the hypothesis of differences in the scores given to the independent variables between the consumer groups can be accepted.

Box's M test showed that the $F$-statistic was 2.85 , with a significance level of 0.0001 . With this, we can reject the null hypothesis that the variance-covariance matrices present no statistically significant differences between the groups of clients. Finally, the confusion matrix shows that 96.8 per cent of the originally grouped cases were correctly classified. All of the above confirms that the three clusters obtained were different and correctly identified.

In general, the analysis corroborates earlier findings (Batra and Ahtola, 1990; Fuljahn and Moosmayer, 2011) that all consumer groups appreciate fast-food restaurants' efforts to provide them with some combination of hedonic and utilitarian benefits, albeit to varying extents.

Table III shows the differences in the three clusters' consumer habits in terms of the variables previously reviewed (e.g. Kendrick, 1998).

In general, the customers from the sample were heavy fast-food restaurant users: 73.5 per cent ate at such restaurants one or more times a week. Nonetheless, the groups exhibited profound differences in usage: The "mainly utilitarian" consumers were the least likely to patronise this type of restaurant, while consumers in the other two groups ate at them several times a week or even every day. It is notable that those clients least sensitive to price (the "ethical values" group) were also the most likely to eat at fast-food restaurants. In line with the practical recommendations of Anderson and Mirosa (2014), this latter finding might indicate that, amidst some restaurant operators' efforts to present a "healthier" image, some consumers may perceive them as quick service restaurants with healthy food options.

With regard to dining companions, the customers in the sample generally went to the restaurants with their friends, family or partners (82.5 per cent in all). Of the rest, 10.25 per cent went alone and 7.25 per cent went with colleagues from work. In terms of between-group differences, those who ate with friends were mainly from the "mainly

\begin{tabular}{|c|c|c|c|c|c|c|}
\hline \multirow[b]{2}{*}{ Variable } & \multirow[b]{2}{*}{$\%$} & \multirow[b]{2}{*}{$\chi^{2}$} & \multicolumn{2}{|c|}{ Percentages by groups } & \multirow[b]{2}{*}{ Ethical values } & \\
\hline & & & Mainly utilitarian & Mainly hedonic & & \\
\hline Frequency of visit & & $p<0.001$ & & & & \\
\hline Less than once a month & 17.25 & & 24.64 & 7.29 & 16.87 & \\
\hline Once a month & 8.75 & & 16.67 & 8.33 & 2.41 & \\
\hline Once a week & 25.50 & & 28.26 & 27.08 & 22.29 & \\
\hline Several times a week & 32.00 & & 21.01 & 38.54 & 37.35 & \\
\hline Every day & 16.50 & & 9.42 & 18.75 & 21.08 & \\
\hline Companions & & $p=0.024$ & & & & \\
\hline Alone & 10.25 & & 10.14 & 10.42 & 10.24 & \\
\hline Family & 20.50 & & 9.42 & 29.17 & 24.70 & \\
\hline Friends & 37.25 & & 44.93 & 31.25 & 34.34 & \\
\hline Partner & 24.75 & & 27.54 & 22.92 & 23.49 & \\
\hline Colleagues & 7.25 & & 7.97 & 6.25 & 7.23 & \\
\hline Expenditure per person & & $p=0.258$ & & & & \\
\hline Less than 6 euros & 21.50 & & 23.91 & 18.75 & 21.08 & \\
\hline From 6-11 euros & 44.50 & & 46.38 & 46.88 & 41.57 & Table III. \\
\hline From $12-17$ euros & 24.50 & & 24.64 & 26.04 & 23.49 & Inter-group differences \\
\hline Over 17 euros & 9.50 & & 5.07 & 8.33 & 13.86 & in consumer habits \\
\hline
\end{tabular}

Consumers' behaviour in fast-food restaurants 
utilitarian" group, while those who went with their families were mainly from the "mainly hedonic" and "ethical values" groups. Members of the "mainly utilitarian" group hardly went to fast-food restaurants with their families at all.

We observed no meaningful differences in average per capita expenditure. The largest share of the sample ( 44.5 per cent) spent between 6 and 11 euros per person. The members of the "mainly utilitarian" group were the most price-sensitive and patronised restaurants less frequently in order to spend less.

With regard to satisfaction, customers were generally satisfied with the food at the restaurant and with the establishment itself (a score of more than 3 on a scale from 1 to 5). The most satisfied clients were those from the "mainly hedonic" group (score of approximately 4), while the least satisfied were those from the "ethical values" group (see Table IV).

An examination of the previous table illuminates several interesting findings. First, all customer groups presented higher scores on those variables related to satisfaction with the food, satisfaction with the establishment, and trust, but lower scores for loyalty. In other words, customers had the most appreciation for variables related to the short and medium term.

With regard to the short term, people presented higher satisfaction scores for the food compared to the establishment itself. For the medium term, it seems important that the scores on the trust variables paralleled those on the satisfaction variables. With regard to the long term, there were three loyalty variables that received scores lower to 3 . From highest to lowest score: "meals outside the home are consumed at this establishment", "best option for food away from home" and "likelihood to recommend the establishment". Notably, although the loyalty variable "regular visits to the establishment" had a higher score than its peers, it might reflect a mere routine behaviour more than actual loyalty.

Additionally, we observed that the mainly hedonic group had the overall highest scores, while the ethical values group had the overall lowest scores. As for trust, the data were generally similar to those on satisfaction (with scores of over 3 points). Therefore, it seems that the "mainly hedonic" customer group tends to present higher scores in satisfaction, trust and loyalty. In contrast, the customer group that primarily values aspects related to health, the environment, and social responsibility presented lower scores in all these variables. This latter finding might suggest that fast-food restaurants have not successfully linked their image to ethical values.

Inter-group differences were mainly found among customers from the "mainly hedonic" group, who maintained a very strong trust in the restaurant (score of around 4). We performed an ANOVA and a Mann-Whitney U test on the "mainly utilitarian" and "ethical values" groups to establish whether the two clusters differed. Both tests revealed statistically significant differences for only three variables: the establishment's honesty, the qualifications of its employees and its technical resources. The "ethical values" group consistently gave higher scores to the first two variables.

\section{Conclusions}

The present study aimed to understand how consumers' food values relate to their behaviours at fast-food restaurants. To this end, we joined the food values scale proposed by Lusk and Briggeman (2009) with the FRL model proposed by Grunert et al. (1993) in a survey of fast-food customers in Spain. Overall, the results corroborated the importance of designing segmented strategies in order to garner diverse consumers.

First, we identified three distinct groups of consumers: the "mainly utilitarian" group (32.45 per cent of the sample), which comprises those consumers who place top importance on the price paid for food, but also assign considerable value to appearance and taste; the "mainly hedonic" group (24 per cent of the sample), who place high value on all aspects except for price, and especially on the values of appearance, taste and convenience 


\begin{tabular}{|c|c|c|c|c|c|c|}
\hline Variable & Mean & $\begin{array}{c}\text { ANOVA /H- } \\
\text { Kruskal-Wallis }\end{array}$ & $\begin{array}{l}\text { Averag } \\
\text { Mainly } \\
\text { utilitarian }\end{array}$ & $\begin{array}{l}\text { values for } \\
\text { Mainly } \\
\text { hedonic }\end{array}$ & $\begin{array}{l}\text { roups } \\
\text { Ethical } \\
\text { values }\end{array}$ & $\begin{array}{r}\text { Consumers' } \\
\text { behaviour in } \\
\text { fast-food }\end{array}$ \\
\hline \multicolumn{6}{|l|}{ Satisfaction with the food } & restaurants \\
\hline The food met my expectations & 3.78 & $\begin{array}{l}p<0.001 \\
p<0.001\end{array}$ & 3.94 & 4.07 & 3.48 & \\
\hline The food was satisfactory & 3.76 & $\begin{array}{l}p<0.001 \\
p<0.001\end{array}$ & 3.75 & 4.22 & 3.50 & \\
\hline $\begin{array}{l}\text { Satisfaction with the food prepared in this } \\
\text { establishment }\end{array}$ & 3.69 & $\begin{array}{l}p<0.001 \\
p<0.001\end{array}$ & 3.84 & 4.15 & 3.31 & \\
\hline $\begin{array}{l}\text { Satisfaction with the establishment } \\
\text { Good choice of establishment }\end{array}$ & 3.57 & $\begin{array}{l}p<0.001 \\
p<0.001\end{array}$ & 3.69 & 3.89 & 3.28 & \\
\hline Total satisfaction with this establishment & 3.74 & $\begin{array}{l}p<0.001 \\
p<0.001\end{array}$ & 3.75 & 4.23 & 3.44 & \\
\hline $\begin{array}{l}\text { Total satisfaction compared to other } \\
\text { restaurants }\end{array}$ & 3.39 & $\begin{array}{l}p<0.001 \\
p<0.001\end{array}$ & 3.37 & 3.93 & 3.10 & \\
\hline \multicolumn{7}{|l|}{ Trust } \\
\hline The establishment keeps its promises & 3.54 & $\begin{array}{l}p<0.001 \\
p<0.001\end{array}$ & 3.36 & 4.10 & 3.35 & \\
\hline $\begin{array}{l}\text { Truthfulness of the information provided } \\
\text { by the establishment }\end{array}$ & 3.53 & $\begin{array}{l}p<0.001 \\
p<0.001\end{array}$ & 3.38 & 4.09 & 3.33 & \\
\hline Honesty of the establishment & 3.51 & $\begin{array}{l}p<0.001 \\
p<0.001\end{array}$ & 3.18 & 4.13 & 3.43 & \\
\hline Trust in the establishment's intentions & 3.52 & $\begin{array}{l}p<0.001 \\
p<0.001\end{array}$ & 3.27 & 4.07 & 3.42 & \\
\hline Sincere and honest information & 3.46 & $\begin{array}{l}p<0.001 \\
p<0.001\end{array}$ & 3.21 & 4.15 & 3.27 & \\
\hline Professionalism of the establishment & 3.61 & $\begin{array}{l}p<0.001 \\
p<0.001\end{array}$ & 3.46 & 4.11 & 3.45 & \\
\hline Technical resources of the establishment & 3.57 & $\begin{array}{l}p<0.001 \\
p<0.001\end{array}$ & 3.57 & 3.96 & 3.33 & \\
\hline Qualifications of the workers & 3.46 & $\begin{array}{l}p<0.001 \\
p<0.001\end{array}$ & 3.12 & 3.91 & 3.48 & \\
\hline Concern for client satisfaction & 3.68 & $\begin{array}{l}p<0.001 \\
p<0.001\end{array}$ & 3.49 & 4.17 & 3.56 & \\
\hline Proper treatment received & 3.76 & $\begin{array}{l}p<0.001 \\
p<0.001\end{array}$ & 3.64 & 4.15 & 3.63 & \\
\hline $\begin{array}{l}\text { Ease of obtaining information from the } \\
\text { establishment }\end{array}$ & 3.54 & $\begin{array}{l}p<0.001 \\
p<0.001\end{array}$ & 3.27 & 4.13 & 3.42 & \\
\hline \multicolumn{7}{|l|}{ Loyalty } \\
\hline $\begin{array}{l}\text { Meals outside the home are consumed at } \\
\text { this establishment }\end{array}$ & 2.71 & $\begin{array}{l}p<0.001 \\
p<0.001\end{array}$ & 2.70 & 3.13 & 2.48 & \\
\hline Likelihood to recommend the establishment & 2.83 & $\begin{array}{l}p<0.001 \\
p<0.001\end{array}$ & 2.91 & 3.36 & 2.45 & \\
\hline Best option for food away from home & 2.78 & $\begin{array}{l}p<0.001 \\
p<0.001\end{array}$ & 2.75 & 3.30 & 2.51 & \\
\hline Regular visits to this establishment & 3.64 & $\begin{array}{l}p<0.001 \\
p<0.001\end{array}$ & 3.71 & 3.95 & 3.40 & \\
\hline Regular business with the establishment & 3.54 & $\begin{array}{l}p<0.001 \\
p<0.001\end{array}$ & 3.45 & 3.96 & 3.36 & $\begin{array}{l}\text { Inter-group differences } \\
\text { in satisfaction, }\end{array}$ \\
\hline Note: Scale of 1 to 5 & & & & & & trust and loyalty \\
\hline
\end{tabular}


(relative to other clusters); and finally, the "ethical values" group (41.5 per cent of the sample), who most identify with a range of values related to safety, the environment and social responsibility. In addition, and in line with reviews of the relevant literature, all consumer groups seemed to appreciate fast-food restaurants' efforts to combine hedonic and utilitarian benefits, albeit to varying extents.

Second, even though most of the respondents were heavy fast-food restaurants users, there were some interesting differences between them: those clients least sensitive to price (the "ethical values" group) were also the most likely to eat at fast-food restaurants. The more that fast-food restaurants position themselves as having healthy options, the more they might attract consumers from this group. Moreover, we found that the majority of consumers went to the restaurants with their friends, family or partners (82.5 per cent in all). Consumers who ate with friends were mainly from the mainly utilitarian group, whilst those who went with their families were mainly from the mainly hedonic and ethical values groups. Members of the "mainly utilitarian" group hardly went to fast-food restaurants with their families at all. No significant differences were observed in average per capita expenditure, being the largest share of the sample spent between 6 and 11 euros per person.

Third, we observed that all customer groups expressed higher scores for variables related to satisfaction with the food, satisfaction with the establishment and trust, but lower scores for loyalty. It seems that customers had the most appreciation for the variables related to the short term (satisfaction) and medium term (trust). Thus, restaurant managers may struggle with achieving the long-term outcome (loyalty to the store), as consumers do not seem to appreciate fast-food restaurants in that way. Moreover, the high scores among the mainly hedonic group, coupled with the low scores of the ethical values group, may reflect such restaurants' reputation as being contrary to ethical values.

Several interesting recommendations can be drawn from these findings. For instance, all consumer groups appeared to value the restaurants' efforts to provide them with a combination of hedonic and utilitarian benefits. Thus, these restaurants should continue to enhance or improve the presence of values related to such benefits. In doing so, these values may translate from the establishment's image to the corporate image. In addition, managers should analyse why consumers do not exhibit a real loyalty to the establishment in the long term, despite their routine behaviour of repeatedly visiting the store. It is important to understand the real limits on attracting loyal customers, who are pivotal to the establishment's long-term survival.

One way to boost customer loyalty might be to address the market gap between fast-food restaurants and "ethical values" customers. Such consumers might discover a greater interest in visiting fast-food restaurants if they exhibit more concern for the environment and social responsibility. In this sense, advertising campaigns focussed solely on the health quality of food might be sub-optimal for attracting this customer segment. However, attracting these customers will require not only better communication, but also incremental innovation through the development of, for example, healthier meals and greater environmental activism.

It is worth adding that the "mainly hedonic" customers placed substantial importance (relative to the other two groups) on the issue of trust, particularly as it concerns the delivery of the service. From a business perspective, this suggests that restaurants should undertake specific actions to increase trust. These actions might include providing more information on calories and nutritional values, as that is where the greatest informational asymmetries have been identified.

Finally, we found that customer satisfaction does not meaningfully contribute to customer loyalty, at least in this context. Indeed, consumers concerned about health, the environment and social responsibility were the least loyal, and yet 58.43 per cent of them frequent these types of fast-food restaurants several times a week or more. This finding 
aligns with Carpenter (2008), who established that consumer behaviour may be repeated more out of necessity. The high frequency with which a customer buys a product may be due more to a lack of appealing alternatives than to an attitude of loyalty (Hobbs and Rowley, 2008). In other words, in the context of this research, they may be patronising the restaurant without any true loyalty to the brand based on affect or loyalty intention (Oliver, 1997). These may represent a compelling opportunity for companies in the industry, which should thus work to develop or increase production and distribution practice initiatives related to these aspects.

\section{References}

Abdullah, F., Zainoren, A. and Hamali, J. (2011), "Managing customer preference for foodservice industry", International Journal of Innovation, Management and Technology, Vol. 6 No. 6 , pp. 525-533.

Arnold, M.J. and Reynolds, K.E. (2003), "Hedonic shopping motivations", Lournal of Retailing, Vol. 79 No. 2, pp. 77-95.

Anderson, E.W. and Fornell, C. (2000), "Foundations of the American Customer Satisfaction Index", Total Qualitv Management, Vol. 1 No. 7, pp. 869-883.

Anderson, E.W. and Sullivan, M.W. (1993), "The antecedents and consequences of customer satisfaction for firms", Marketing Science, Vol. 12 No. 99, pp. 125-143.

Anderson, K. and Mirosa, M. (2014), "Revealing barriers to healthier fast-food consumption choices", British Food Journal, Vol. 116 No. 5, pp. 821-831.

Ayechu, A. and Durá, T. (2010), "Calidad de los hábitos alimentarios (adherencia a la dieta mediterránea) en los alumnos de educación secundaria obligatoria”, Anales del sistema sanitario de Navarra, Vol. 33 No. 1, pp. 35-42.

Batra, R. and Ahtola, O.T. (1990), "Measuring the hedonic and utilitarian sources of con.sumcr attitudes", Marketing Letters, Vol. 2 No. 2, pp. 159-170.

Bolton, R.N. and Drew, J.H. (1991), "A longitudinal analysis of the impact of service changes on customer attitudes", Journal of Marketing, Vol. 55 No. 1, pp. 1-9.

Boulding, W., Kalra, A., Staelin, R. and Zeithaml, V.A. (1993), "A dynamic process model of service quality: from expectations to behavioral intentions", Journal of Marketing Research, Vol. 30, February, pp. 7-27.

Bowen, J.T. and Chen, S.-L. (2001), "The relationship between customer loyalty and customer satisfaction”, International Journal of Service Industry Management, Vol. 15 No. 4, pp. 213-217.

Bredahl, L. (2001), "Determinants of consumer attitudes and purchase intentions with regard to genetically modified foods - results of a cross-national survey", Lournal of Consumer Policv, Vol. 24 No. 1, pp. 23-61.

Caixabank Research (2014), available at: www.caixabankresearch.com/geographic-areas/economia-espanola

Carpenter, J.M. (2008), "Consumer shopping value, satisfaction and loyalty in discount retailing", Journal of Retailing and Consumer Services, Vol. 15, pp. 358-363.

Clemente-Ricolfe, S. and Gómez Layana, B. (2006), "Posicionamiento de los restaurantes de comida rápida”, Boletín económico de ICE, Información Comercial Española, Vol. 2898, pp. 51-59.

Currie, J., DellaVigna, S., Moretti, E. and Pathania, V. (2010), "The effect of fast-food restaurants on obesity and weight gain", American Economic Iournal: Economic Policy, Vol. 2, August, pp. 32-63.

Darian, J.C. and Cohen, J. (1995), "Segmenting by consumer time shortage", Lournal of Consumer Marketing, Vol. 12 No. 1, pp. 32-44.

De Ruyter, K., Wetzels, M. and Bloemer, J. (1998), "On the relationship between perceived service quality, service loyalty and switching costs", International Iournal of Service Industrv Management, Vol. 9 No. 5, pp. 436-453.
Consumers'

behaviour in fast-food restaurants 
Dick, A. and Basu, K. (1994), "Customer loyalty: toward an integrated conceptual framework", Journal of the Academy of Marketing Science, Vol. 22 No. 2, pp. 99-113.

Erdem, T. and Swait, J. (2004), "Brand credibility, brand consideration, and choice", Journal of Consumer Research, Vol. 31 No. 1, pp. 191-198.

Fàbrega, J. (2004), “Comida rápida, comida lenta: ¿cultura o barbarie?”, Mètode No. 40, febrero, pp. 77-82.

Fuljahn, A. and Moosmayer, D.C. (2011), "The Myth of Guilt: a replication study on the suitability of hedonic and utilitarian products for cause related marketing capaigns in Germany", International Journal of Business, Research, pp. 85-92.

Grunert, K.G. (1993), “Toward a concept of food-related lifestyle”, Appetite, Vol. 21 No. 2, pp. 151-155.

Grunert, K.G., Brunsø, K. and Bisp, S. (1993), "Food-related lifestyle: development of a cross-culturally valid instrument for market surveillance", MAPP Working Paper No. 12, pp. 1-38.

Irani, N. and Heidorzaden, K. (2011), "The effects of Iranian consumers' buying tendencies on hedonic and utilitarian shopping value", African Journal of Business Management, Vol. 5 No. 17, pp. 7449-7460.

Hirschman, E.C. and Holbrook, M.B. (1982), "Hedonic consumption: emerging concepts, methods and propositions", Journal of Marketing, Vol. 46 No. 3, pp. 92-101.

Hobbs, R. and Rowley, J. (2008), "Are pub discount cards loyalty cards?", Journal of Consumer Marketing, Vol. 25 No. 6, pp. 369-377.

Jacoby, J. and Chesnut, R.W. (1978), Brand Loyalty Measurement and Management, John Wiley and Sons, New York, NY, 120pp.

Kara, A., Kaynak, E. and Kucukemiroglu, O. (1995), "Marketing strategies for fast-food restaurants: a customer view", International Journal of Contemporary Hospitality Management, Vol. 7 No. 4, pp. 16-22.

Kendrick, A. (1998), "Promotional products vs price promotion in fostering customer loyalty: a report of two controlled field experiments", The Journal of Service Marketing, Vol. 12 No. 4, pp. 312-326.

Kivela, J.J. (1997), "Restaurant marketing: selection and segmentation in Hong Kong", International Journal of Contemporary Hospitality Management, Vol. 9 No. 3, pp. 116-123.

Koo, L.C., Tao, F.K.C. and Yeung, J.H.C. (1999), "Preferential segmentation of restaurant attributes through conjoint analysis", International Journal of Contemporary Hospitality Management, Vol. 11 No. 5, pp. 242-253.

Kumar, V. and Shah, D. (2004), "Building and sustaining profitable customer loyalty for the 21st century", Journal of Retailing, Vol. 80 No. 4, pp. 317-329.

Law, A.K.Y., Hui, Y.V. and Zhao, X. (2004), "Modeling repurchase frequency and customer satisfaction for fast-food outlets", The International Journal of Quality and Reliability Management, Vol. 21 No. 5, pp. 545-563.

Libremercado (2016), "Quién domina el Mercado de la comida rápida en España”, available at: www. libremercado.com/2016-01-24/quien-domina-el-mercado-de-la-comida-rapida-en-espana-1276565960/

Lovelock, C. and Wright, L. (2002), "Service marketing and management. Loyalty and switching costs", International Journal of Service Industry Management, Vol. 9 No. 5, pp. 436-453.

Lusk, J.L. and Briggeman, B.C. (2009), "Food values", American Journal of Agricultural Economics, Vol. 91 No. 1, pp. 184-196.

Martínez-Ruiz, M.P. and Gómez-Cantó, C.M. (2016), "Key external influences affecting consumers' decisions regarding food", Frontiers in Psychology, October, available at: www.frontiersin.org/ articles/10.3389/fpsyg.2016.01618/full

Maehle, M, Iversen, Nina, M., Leif, H. and Otnes, C.C. (2015), "Exploring consumer preferences for hedonic and utilitarian food attributes", British Food Journal, Vol. 117 No. 12, pp. 3039-3063.

Momtaz, N.J., Alizadeh, S. and Vaghefi, M.S. (2013), "A new model for assessment fast-food customer behavior case study: an Iranian fast-food restaurant”, British Food Journal, Vol. 115 No. 4, pp. 601-613. 
Oliver, R.L. (1997), Customer Satisfaction: A Behavioral Perspective on the Consumer, McGraw-Hill, New York, NY.

Parasuraman, A., Zeithaml, V.A. and Berry, L.L. (1985), "A conceptual model of service quality and its implications for future research", Journal of Marketing, Vol. 49 No. 4, pp. 41-50.

Qin, H. and Prybutok, R.V. (2008), "Determinants of customer-perceived service quality in fast-food restaurants and their relationship to customer satisfaction and behavioral intentions", The Quality Management Journal, Vol. 15 No. 2, pp. 35-50.

Qin, H. and Prybutok, V.P. (2009a), "Determinants of customer-perceived service quality in fast-food restaurants and their relationship to customer satisfaction and behavioral intentions", The Quality Management Journal, Vol. 15 No. 2, pp. 35-50.

Qin, H. and Prybutok, V.P. (2009b), "Service quality, customer satisfaction and behavioral intentions in fast-food restaurants", International Journal of Quality and Service Sciences, Vol. 1 No. 1, pp. 78-95.

Qin, H., Prybutok, V.P. and Zhao, Q. (2010), "Perceived service quality in fast-food restaurants: empirical evidence from China", International Journal of Quality \& Reliability Management, Vol. 27 No. 4, pp. 424-437.

Rust, R.T. and Oliver, R.L. (1994), Service Quality, Insights and Managerial Implications from the Frontier, Sage, London.

Ruyter, K., Wetzels, M. and Bloemer, J. (1998), "On the relationship between perceived service quality, service loyalty and switching costs", International Journal of Service Industry Management, Vol. 9 No. 5, pp. 436-453.

Ryu, K., Han, H. and Jang, S. (2010), "Relationships among hedonic and utilitarian values, satisfaction and behavioral intentions in the fat-casual restaurant industry", International Journal of Contemporary Hospitality Management, Vol. 22 No. 3, pp. 416-432.

Schroeder, M.J.A. and McEachern, M.G. (2005), "Fast-foods and ethical consumer value: a focus on McDonald's and KFC", British Food Journal, Vol. 107 No. 4, pp. 212-224.

Strahilevitz, M. and Myers, J.G. (1998), "Donations to charity as purchase incentives: how well they work may depend on what you are trying to sell”, Journal of Consumer Research, Vol. 24 No. 4, pp. 434-446.

Steenkamp, J.E.B.M. and Van Trijp, J.C.M. (1990), "Quality guidance: a consumer based approach for product quality improvement", in Avlonitis, G.J. (Ed.), Marketing Thought and Practice in the 1990s: Proceedings of the 18th Annual Meeting of the European Academy, Vol. II, EMAC, Athens, pp. 1191-1217.

Tarn, J.L.M. (1999), "The effects of service quality, perceived value and customer satisfaction on behavioral intentions", Journal of Hospitality \& Leisure Marketing, Vol. 6 No. 4, pp. 31-43.

Tong, C. and Wong, A. (2016), "The effects of corporate social responsibility of fast-food restaurants on corporate reputation", Journal of Marketing and HR, Vol. 3 No. 1, pp. 126-144.

Worsley, A. and Lea, E. (2008), "Consumer concerns about food and health. Examination of general and specific relationships with personal values and demographics", British Food Journal, Vol. 110 No. 11, pp. 1106-1118.

$\mathrm{Xu}, \mathrm{Y}$. (2014), "Understanding CSR from the perspective of Chinese diners: the case of McDonald's", International Journal of Contemporary Hospitality Management, Vol. 26 No. 6, pp. 1002-1020.

Zopiatis, A. and Pribic, J. (2007), “College students' dining expectations in Cyprus”, British Food Journal, Vol. 109 No. 10, pp. 765-776.

\section{Further reading}

Bredahl, L. and Grunert, K.G. (1997), "Food-related lifestyle trends in Germany 1993-1996", MAPP working paper, The Aarhus School of Business, Aarhus.

Brown, K., Mcllveen, H. and Strugnell, C. (2000), "Nutritional awareness and food preferences of young consumers", Nutrition and Food Science, Vol. 30 No. 5, pp. 230-235.
Consumers'

behaviour in fast-food restaurants 
Brunsø, K., Scholderer, J. and Grunert, K.G. (2004), "Closing the gap between values and behavior -a means-end theory of lifestyle", Journal Business Research, Vol. 57 No. 6, pp. 665-670.

Bryant, R. and Dundes, L. (2008), "Fast-food perceptions: a pilot study of college students in Spain and the United States", Appetite, Vol. 51 No. 2, pp. 327-330.

Iglesias, M.P. and Guillen, M.J.Y. (2004), "Perceived quality and price: their impact on the satisfaction of restaurant customers", International Journal of Contemporary Hospitality Management, Vol. 16 No. 6, pp. 373-379.

Islam, N., Ullah, G.M. and Shafayer (2010), "Factors affecting consumers' preferences on fast-food items in Bangladesh", The Journal of Applied Business Research, Vol. 26 No. 4, pp. 131-146.

McMahon, A.T., Williams, P. and Tapsell, L. (2010), "Reviewing the meanings of wellness and wellbeing and their implications for food choice", Perspectives in Public Health, Vol. 130 No. 6, pp. $282-286$.

Park, C. (2004), "Efficient or enjoyable? Consumer values of eating-out and fast-food restaurant consumption in Korea", International Journal of Hospitality Management, Vol. 23 No. 1, pp. 87-94.

Togersen, J. (2017), "Sustainable food consumption in the nexus between national context and private lifestyle: a multi-level study", Food Quality and Preference, Vol. 55, January, pp. 16-25.

Tse, A.C.B. (2001), "How much more are consumers willing to pay for a higher level of service? A preliminary survey", Journal of Service Marketing, Vol. 15 No. 1, pp. 11-17.

\section{Corresponding author}

María Pilar Martínez-Ruiz can be contacted at: MariaPilar.Martinez@uclm.es

For instructions on how to order reprints of this article, please visit our website: 